\title{
ARTIGO
}

dO https://doi.org/10.22481/praxisedu.v15i34.5802

\section{LABOR PRODUCTIVITY AS A PRODUCTION EFFICIENCY FACTOR}

\author{
PRODUCTIVIDAD LABORAL COMO FACTOR DE EFICIENCIA DE PRODUCCIÓN
}

PRODUTIVIDADE DO TRABALHO COMO FATOR DE EFICIÊNCIA DA PRODUÇÃO

A.V. Kolesnikov

Belgorod State Technological University named after V.G. Shukhov - Russia

E.Yu. Kamchatova

State University of Management - Russia

I.V Boyarinova

Belgorod State National Research University - Russia

L.A. Reshetnyak

Belgorod State Agricultural University named after V.Ya. Gorin - Russia

O.I. Zolotareva

Belgorod State Agricultural University named after V.Ya. Gorin - Russia

S.N. Zolotarev

Belgorod State Agricultural University named after V.Ya. Gorin - Russia

I.A. Demesheva

Belgorod State Agricultural University named after V.Ya. Gorin - Russia

Resumo: O objetivo desta investigação é estudar o fator de eficiência e a produtividade do trabalho. Em grande medida, o nível de produtividade do trabalho aumentou devido à intensificação da produção. Ao mesmo tempo, segundo Rosstat, na agricultura, silvicultura e pesca, existem apenas $8 \%$ dos empregos de alta eficiência. Assim, o fator de intensificação da produção é usado de forma insignificante. É óbvio que é necessário um componente inovador do crescimento da produtividade do trabalho, por um lado, e a criação de novos empregos nas áreas rurais para os recursos liberados, por outro. Aqui é necessário determinar os principais fatores que afetam a produtividade nas condições modernas e justificar propostas para melhorála.

Palavras-chave: Produtividade do trabalho; Salários; Intensificação da produção; Apoio estatal; Empregos de alta eficiência. 


\begin{abstract}
Of the goal of this investigation is to study the efficiency factor and labor productivity. To a large extent, the level of labor productivity grew due to the intensification of production. At the same time, according to Rosstat, in agriculture, forestry and fisheries there are only $8 \%$ of high-efficient jobs. Thus, the factor of production intensification is used insignificantly. It is obvious that there is a need for an innovative component of labor productivity growth on the one hand, and the creation of new jobs in rural areas for the released labor resources, on the other hand. Here it is necessary to determine the main factors affecting productivity in modern conditions, and to justify proposals to improve it.
\end{abstract}

Keywords: Labor productivity; Wages; Production intensification; State support; Highefficient jobs.

Resumen: El objetivo de esta investigación es estudiar el factor de eficiencia y la productividad laboral. En gran medida, el nivel de productividad laboral creció debido a la intensificación de la producción. Al mismo tiempo, según Rosstat, en agricultura, silvicultura y pesca solo hay un $8 \%$ de empleos altamente eficientes. Por lo tanto, el factor de intensificación de la producción se utiliza de manera insignificante. Es obvio que hay una necesidad de un componente innovador del crecimiento de la productividad laboral, por un lado, y la creación de nuevos empleos en las zonas rurales para los recursos laborales liberados, por otro lado. Aquí es necesario determinar los principales factores que afectan la productividad en las condiciones modernas, y justificar las propuestas para mejorarla.

Palabras clave: Productividad laboral; Salarios; Intensificación de la producción; Apoyo estatal; Empleos de alta eficiencia.

\title{
Introduction
}

As you know, the level of wages in agriculture in Russia is one of the lowest, and this is despite the increase in the cost of gross agricultural output, the use of new equipment and technologies (Ashmarov, 2017; Minakova, 2017; Gnatyuk \& Pekert, 2018; Olkhovskiy, 2018; Narkevich \& Narkevich, 2018; Novikov, 2017; Schwarzkopf, 2018; Moiseenko, 2017). Traditionally, labor productivity is influenced by such components as the amount of gross output, the number of agricultural workers, the level of using machinery and technology, the intensity of production, the scale of production, the level of its concentration and specialization, and many others. The category of labor productivity is multidimensional and covers all components of economic activity of any economic entity. In this regard, it is important to know 
the impact of what factors, in modern conditions, the productivity is most affected with and how it affects the level of wages (Bogatov et al., 2017; Shcherbinina, 2017; Moiseenko, 2017; Komarova, 2018; Kobets, 2017; Kupryushin \& Chernyatina, 2017; Narkevich, 2018; Vernigor, 2017).

\section{Goals And Objectives Of The Study}

The problem of increasing productivity in agriculture is one of the key. The solution of this problem is the basis for a motivated increase in wages of employees. In this regard, the goal of this study is to determine the factors affecting productivity in modern conditions. To achieve this goal, the following objectives were solved:

- to give a current assessment of productivity;

- to determine the factors affecting labor productivity in modern conditions;

- to justify offers to improve labor productivity.

\section{Research Results}

Currently, the main part of agricultural products are produced by large trade agricultural organizations. Their share in the structure of gross output is $55.1 \%$, although 18 years ago it was only $45.2 \%$. During this time, the state has taken the path to the development of large trade agricultural production, as it is able to provide food security of the country, the population with jobs, to provide mass production at the lowest cost.

Table 1: Structure of agricultural products by categories of farms (in actual prices, $\%$ of total) (Russia in numbers, 2018)

\begin{tabular}{|l|c|c|c|c|c|}
\hline & \multicolumn{5}{|c|}{ Years } \\
\cline { 2 - 6 } & 1990 & 2000 & 2005 & 2015 & 2018 \\
\hline Farms of all categories & 100 & 100 & 100 & 100 & 100 \\
\hline $\begin{array}{l}\text { including: } \\
\text { agricultural organizations }\end{array}$ & 73,7 & 45,2 & 44,6 & 53,9 & 55,1 \\
\hline Households & 26,3 & 51,6 & 49,3 & 34,6 & 33,0 \\
\hline Peasant farms & $\ldots$. & 3,2 & 6,1 & 11,5 & 11,9 \\
\hline
\end{tabular}

As you know, agriculture is currently a dynamically developing industry. Good dynamics of gross production of almost all types of agricultural products, the use of modern 
equipment and technologies should contribute to an increase in wages, at least at a rate that gross output increases.

Agriculture in Russia shows not only an increase in gross output, but also investment and exports. All these are the results of the agrarian and food policy pursued by the state. For 2000-2017, the gross harvest of grain crops increased more than 2 times, sugar beet 3.7 times, sunflower 2.7 times. Agriculture of Russia demonstrates not only the increase in amount. The amount of pork production increased almost 2 times, and a significant increase is for the beginning of the PNP "Development of agriculture". This project really gave impetus to the qualitative development of agriculture and related industries. Over 18 years of agrarian reforms, gross agricultural output increased by 6.8 times, the amount of investments by 11.9 times, the number of profitable enterprises by $23.5 \%$, the net profit by 6 times. It would seem good results. These are certainly positive developments, but the agricultural economy could grow faster if we consider that more than 100 million hectares of agricultural land were eliminated from the turnover according to the all-Russian agricultural census, and the level of wages in agriculture leaves much to be desired.

Table 2: Main economic indicators of agricultural production in Russia in 2000-2017 (Russia in numbers, 2018)

\begin{tabular}{|c|c|c|c|c|c|c|c|}
\hline \multirow[b]{2}{*}{ № } & \multirow[b]{2}{*}{ Indicators } & \multicolumn{4}{|l|}{ Years } & \multicolumn{2}{|l|}{2017} \\
\hline & & 2000 & 2005 & 2016 & 2017 & $\begin{array}{l}\text { to } 2000 \\
(+;-)\end{array}$ & $\begin{array}{l}\text { to } 2000 \text {, } \\
\%\end{array}$ \\
\hline 1 & $\begin{array}{l}\text { Gross output in current } \\
\text { prices total, billion rubles }\end{array}$ & 742,4 & 1380,9 & 5119,2 & 5119,9 & 4377,5 & $\begin{array}{l}\text { by } 6,8 \\
\text { times }\end{array}$ \\
\hline 2 & $\begin{array}{l}\text { Area of arable land, } \\
\text { thousand hectares }\end{array}$ & 84670 & 75837 & 79312 & 80048 & -4622 & 94,5 \\
\hline 3 & $\begin{array}{l}\text { Investments in fixed } \\
\text { assets, billion rubles }\end{array}$ & 34,8 & 142,3 & 611,2 & 412,5 & 377,7 & $\begin{array}{l}\text { by } 11,9 \\
\text { times }\end{array}$ \\
\hline 4 & $\begin{array}{l}\text { Invested in } 1 \text { ha of arable } \\
\text { land, rubles }\end{array}$ & 411 & 1877 & 7700 & 5156 & 4745 & $\begin{array}{l}\text { by } 12,5 \\
\text { times }\end{array}$ \\
\hline \multicolumn{8}{|c|}{ Gross yield, million tons } \\
\hline 5 & $\begin{array}{l}\text { Grain (in weight after } \\
\text { completion) }\end{array}$ & 65,4 & 77,8 & 120,7 & 135,4 & 70 & $\begin{array}{l}\text { more } \\
\text { than } 2 \\
\text { times }\end{array}$ \\
\hline 6 & Sugar beet & 14,1 & 21,3 & 51,4 & 51,9 & 37,8 & $\begin{array}{l}\text { by } 3,7 \\
\text { times }\end{array}$ \\
\hline 7 & Sunflower & 3,9 & 6,5 & 11,0 & 10,5 & 6,6 & $\begin{array}{l}\text { by } 2,7 \\
\text { times }\end{array}$ \\
\hline \multicolumn{8}{|c|}{ Livestock production } \\
\hline 8 & Milk, million tons & 32,3 & 31,1 & 30,8 & 31,2 & $-0,1$ & 99,4 \\
\hline
\end{tabular}




\begin{tabular}{|c|c|c|c|c|c|c|c|}
\hline 9 & Cattle, million tons & 1,9 & 1,8 & 1,6 & 1,6 & $-0,3$ & 84,2 \\
\hline $\begin{array}{l}1 \\
0\end{array}$ & Pigs, million tons & 1,6 & 1,6 & 3,4 & 3,5 & 1,9 & $\begin{array}{l}\text { by } 2,1 \\
\text { times }\end{array}$ \\
\hline $\begin{array}{l}1 \\
1\end{array}$ & $\begin{array}{l}\text { Average monthly salary, } \\
\text { rubles }\end{array}$ & 985 & 3646 & 22915 & 25671 & 24686 & $\begin{array}{l}\text { by } 26,1 \\
\text { times }\end{array}$ \\
\hline $\begin{array}{l}1 \\
2\end{array}$ & $\begin{array}{l}\text { Share of profitable } \\
\text { farms, } \%\end{array}$ & No & 58,8 & 78,8 & 82,3 & $\begin{array}{l}23,5 \quad(\kappa \\
2005)\end{array}$ & $\begin{array}{l}\text { by1,4 } \\
\text { times } \\
\text { (to } \\
2005 \text { ) }\end{array}$ \\
\hline $\begin{array}{l}1 \\
3\end{array}$ & $\begin{array}{l}\text { Profit - total, million } \\
\text { rubles (netted) }\end{array}$ & NO & 30764 & 239444 & 186217 & $\begin{array}{l}155453 \\
(\kappa \\
2005)\end{array}$ & $\begin{array}{l}\text { by } 6 \\
\text { times } \\
\text { (to } \\
\text { 2005) }\end{array}$ \\
\hline
\end{tabular}

If 100 million hectares of agricultural land were cultivated, the amount of gross output could be about 9-11 trillion rubles, instead of 5.5 trillion rubles, respectively, and the level of exports would be about 1.5-2 times higher.

The result of the conducted agrarian and food policy was an increase in the number of profitable organizations, the net financial result increased, which is associated with the strengthening of technological discipline and the renewal of material and technical resources, the selection of qualified personnel at all levels of agro-industrial production.

Despite the dynamic growth of the main production indicators, the level of wages in agriculture remains one of the lowest in the economy, thus not providing a decent purchasing power of the villagers, and not helping to attract young professionals to the village.

The main source of income, both in urban and rural areas is cash income received, usually in the form of wages. In rural areas, up to $88 \%$ of income is generated from cash receipts, while in the city this figure is $90.4 \%$. Over the past 18 years, the level of wages of workers in rural and urban areas has differed significantly.

Even in modern conditions, wages are not the main motive for working in rural areas. It is at least $35 \%$ less than in the city, without performing any motivating function, and not fully fulfilling the social function. So in 2000, the level of wages in rural areas was $44.3 \%$ of the same indicator in the city. And only with the beginning of the PNP "Development of agriculture" and the implementation of the State Program, the situation has moved forward. In 2008 , the ratio of rural to urban wages was $49 \%$, and in 2017 it was $65.5 \%$. On this basis, it can be argued that the purchasing power of the rural population is $35 \%$ lower than that of the urban population. Villagers receiving lower wages are disadvantaged in their rights to access the benefits that urban residents can afford, and not because they do not have them in the village, but because their level of income is significantly less than that of urban residents. All this forms 
a stable negative attitude to life in rural areas and to the people living there. And this is despite the rapid growth of agricultural production, investment, introduction of new technologies, faster growth of labor productivity, etc.

Table 3: The ratio of wages in agriculture to wages on average in the economy

\begin{tabular}{|c|c|c|c|c|c|c|c|}
\hline Years & $\begin{array}{c}\text { In the } \\
\text { economy }\end{array}$ & $\begin{array}{c}\text { In the } \\
\text { agriculture }\end{array}$ & $\begin{array}{c}\text { Ratio }, \\
\text { \% }\end{array}$ & Years & $\begin{array}{c}\text { In the } \\
\text { economy }\end{array}$ & $\begin{array}{c}\text { In the } \\
\text { agriculture }\end{array}$ & $\begin{array}{c}\text { Ratio, } \\
\text { \% }\end{array}$ \\
\hline 2000 & 2223 & 985 & 44,3 & 2010 & 20952 & 10668 & 50,9 \\
\hline 2001 & 3240 & 1435 & 44,3 & 2011 & 23369 & 12464 & 53,3 \\
\hline 2002 & 4360 & 1876 & 43,0 & 2012 & 26629 & 14129 & 53,1 \\
\hline 2003 & 5499 & 2340 & 42,6 & 2013 & 29792 & 15724 & 52,8 \\
\hline 2004 & 6740 & 3015 & 44,7 & 2014 & 32495 & 17724 & 54,5 \\
\hline 2005 & 8555 & 3646 & 42,6 & 2015 & 34030 & 19721 & 58,0 \\
\hline 2006 & 10634 & 4569 & 43,0 & 2016 & 36709 & 21755 & 59,3 \\
\hline 2007 & 13593 & 6144 & 45,2 & 2017 & 39167 & 25671 & 65,5 \\
\hline 2008 & 17290 & 8475 & 49,0 & 2018 & 43445 & 28185 & 64,9 \\
\cline { 1 - 3 } 2009 & 18638 & 9619 & 51,6 & & & & \\
\cline { 1 - 3 }
\end{tabular}

Comparing the growth rates of labor productivity and the average monthly wage, we can say that the producer currently has reserves to increase wages through the introduction of new technologies and modern equipment. And this is despite the fact that in 2017, according to Rosstat, the growth of labor productivity in agriculture amounted to $103.5 \%$, while the economy is only $99.7 \%$ ! The growth rate of gross agricultural output for the same year was $102.7 \%$. It would seem that the growth rate of labor productivity exceeds the growth rate of gross output, but this excess is achieved, including by reducing the number of workers in agriculture. In 20052016, labor productivity increased by almost $30 \%$ due to a decrease in the number of workers employed in agriculture.

In the course of the agrarian and food policy, agricultural enterprises deepened specialization and concentration of production, began to apply new technologies, which contributed to a decrease in the average annual number of workers employed in agriculture by $28.2 \%$, an increase in the accounting value of fixed assets by 3.3 times. Gross production has increased more than 4 times. In the course of agrarian reforms, agricultural producers acquired new high-tech, powerful agricultural machinery and technologies that were able to reduce the consumption of fuels and lubricants, reduced the impact of the human factor. A significant increase in the intensity of production was achieved by reducing costs through the use of highperformance wide-ranging equipment in crop production and new technologies in animal 
husbandry. As a result, the volume of energy capacity in agricultural organizations decreased by $41.2 \%$.

Table 4: Dynamics of labor productivity, capital and energy intensity and number of employees in Russia in 2005-2016 (Russia in numbers, 2018)

\begin{tabular}{|c|c|c|c|c|c|c|}
\hline \multirow[t]{2}{*}{ № } & \multirow[t]{2}{*}{ Indicators } & \multicolumn{3}{|c|}{ Years } & \multicolumn{2}{|c|}{2016} \\
\hline & & 2005 & 2010 & 2016 & $\begin{array}{c}\text { to } 2005 \\
+;-\end{array}$ & $\begin{array}{c}\text { to } \\
2005 \\
\%\end{array}$ \\
\hline 1. & $\begin{array}{l}\text { Average annual } \\
\text { number of } \\
\text { workers employed } \\
\text { in agriculture, } \\
\text { thousand people. }\end{array}$ & 7489 & 6622 & 5374 & -2115 & 71,8 \\
\hline 2. & $\begin{array}{l}\text { Accounting value } \\
\text { of fixed assets, } \\
\text { mln. rubles }\end{array}$ & 1440084 & 2859877 & 4758488 & 3318404 & $\begin{array}{l}\text { by } 3,3 \\
\text { times }\end{array}$ \\
\hline 3. & $\begin{array}{c}\text { Gross output-total, } \\
\text { billion rubles (in } \\
\text { current prices) }\end{array}$ & 1380,9 & 2587,8 & 5505,7 & 4124,8 & $\begin{array}{l}\text { by } 4 \\
\text { times }\end{array}$ \\
\hline 4. & $\begin{array}{l}\text { Energy capacity, } \\
\text { total, million HP }\end{array}$ & 156,9 & 109,9 & 92,3 & $-64,6$ & 58,8 \\
\hline 4.1 . & $\begin{array}{c}\text { per } 1 \text { employee, } \\
\text { HP }\end{array}$ & 58,6 & 66,9 & 77,1 & 18,5 & 131,6 \\
\hline 4.2 . & $\begin{array}{l}\text { per } 100 \text { hectares } \\
\text { of acreage, HP }\end{array}$ & 270 & 227 & 200 & -70 & 74,1 \\
\hline 5. & $\begin{array}{c}\text { Capital intensity, } \\
\text { rubles }\end{array}$ & 192293 & 431875 & 885466 & 693173 & $\begin{array}{l}\text { by } 4,6 \\
\text { times }\end{array}$ \\
\hline 6. & $\begin{array}{l}\text { Labor } \\
\text { productivity, } \\
\text { rubles }\end{array}$ & 184390 & 390788 & 1024507 & 840117 & $\begin{array}{l}\text { by } 5,5 \\
\text { times }\end{array}$ \\
\hline
\end{tabular}


This led to an increase in energy capacity per 1 employee by $31.6 \%$, while the capital intensity increased by 4.6 times. On the one hand, this is explained by the disparity of prices for the purchased equipment, on the other hand, a significant part of the purchased equipment was imported, more expensive than domestic. All of the above had a positive impact on labor productivity, which increased by 5.5 times, including by increasing the amount of gross output by 4 times, and by about 30\% due to a decrease in the number of employees. In 2016, labor productivity in agricultural organizations in Russia was more than 1 million rubles, but in some regions it exceeded 2 , and sometimes 4 million rubles.

As it can be seen from the above data, labor productivity has increased in value terms, which may indicate the effective use of labor resources in agricultural organizations, the creation of high-efficient jobs. But is it really so?

The Russian economy has more than 17 million high-efficient jobs. The leading positions are occupied by: manufacturing, public administration and military support security; social insurance and trade. It is obvious that a certain part of high productivity in public administration is provided by increasing budget financing, and in manufacturing and trade by disparity in relations with agricultural production.

In agricultural production, fish farming and forestry in 2017 there were only 438 thousand jobs, which is about $8 \%$ of all jobs in this sector of the economy. Thus, there are not so many high-efficient jobs in agriculture, and this is despite the state support, the use of new equipment and technologies.

All of the above points to the insufficiently high growth rates of labor productivity and production intensification compared to the growth rates of cost and prices of finished products. And this is despite the fact that agriculture is a subsidized sector of the economy, an investmentattractive industry that can consistently make a profit.

Table 5: Number of high-efficient jobs by type of economic activity for 2013-2016, thousand units (Russia in numbers, 2018)

\begin{tabular}{|l|c|c|c|c|c|}
\hline & \multicolumn{5}{|c|}{ Years } \\
\hline & 2013 & 2014 & 2015 & 2016 & 2017 \\
\hline The Russian Federation & & & & & \\
\hline Total & 17492,8 & 18280,9 & 16782,4 & 15983,3 & 17114,0 \\
\hline $\begin{array}{l}\text { Agriculture, hunting and forestry, } \\
\text { fishing, fish farming }\end{array}$ & 367,3 & 401,2 & 350,4 & 367,3 & 438,8 \\
\hline Extraction of minerals & 878,1 & 852,1 & 854,1 & 852,1 & 875,0 \\
\hline
\end{tabular}




\begin{tabular}{|c|c|c|c|c|c|}
\hline Manufacturing activity & 3670,8 & 3722,9 & 3333,9 & 3214,0 & 3533,9 \\
\hline $\begin{array}{l}\text { Production and distribution of } \\
\text { electricity, gas and water }\end{array}$ & 910,1 & 998,6 & 926,8 & 891,5 & 882,5 \\
\hline Construction & 1046,3 & 1028,0 & 871,9 & 736,3 & 838,2 \\
\hline $\begin{array}{l}\text { Wholesale and retail trade; } \\
\text { repair of motor vehicles, } \\
\text { motorcycles, household goods and } \\
\text { personal items }\end{array}$ & 1479,2 & 1609,4 & 1548,5 & 1535,0 & 1752,9 \\
\hline Hotels and restaurants & 112,8 & 124,3 & 92,2 & 95,3 & 114,8 \\
\hline Transport and communication & 1632,9 & 2092,8 & 1787,7 & 1695,2 & 1407,4 \\
\hline Financial activity & 1064,4 & 949,9 & 907,6 & 853,6 & 834,7 \\
\hline $\begin{array}{l}\text { Real estate transactions, leases and } \\
\text { provision of services }\end{array}$ & 1956,4 & 2070,5 & 1849,2 & 1870,1 & 378,8 \\
\hline $\begin{array}{l}\text { Public administration and military } \\
\text { support security; social insurance }\end{array}$ & 2518,6 & 2458,9 & 2307,4 & 2178,4 & 2070,6 \\
\hline Education & 721,6 & 782,0 & 786,9 & 643,7 & 687,6 \\
\hline
\end{tabular}

The main reason for increasing labor productivity is the intensification of production - increasing the intensity of labor. The use of modern wide-ranging equipment in crop production contributed not only to increase productivity, but also to reduce the cost of fuel per 1 hectare of arable land, improve the quality of agricultural techniques, reduce net costs. Using new high-efficient equipment and technologies, producers release a significant number of jobs, while the state does not conduct an aggressive policy of creating jobs in rural areas. An increase in unemployment in rural areas, urbanization processes, and an increase in the proportion of the elderly population living in rural areas is the result of the introduction of new equipment and technologies.

As practice shows, the labor release from social production, creates a risk of opportunistic relations between private farms and large trade production. Another negative aspect of the labor release is the devastation and extinction of villages. Firstly, this is due to the meager state support for social infrastructure, which in itself does not motivate the population to improve demographics. Secondly, the lack of stable earnings or income contributes to the migration of the rural population in large towns and cities.

The state, not understanding the problems of the villagers, is now completely abstracted from it. It is empirically proved that the level of development of the social sphere in 
rural areas is determined by the level of development of production located in this area. And it does not matter what kind of production is large trade or small trade. The main thing is that production should be self-sufficient, that it should have the necessary number of jobs for rural residents, infrastructure and a sufficiently high level of wages.

From the standpoint of the state, it would be advisable to implement not a declarative regulation of agrarian sector, written in the Law "On agriculture development", but real, with the developed mechanisms of state support and regulation, defined the term financing of the agricultural sector. For example, to regulate the level of production of certain types of products for which there is a steady overproduction, to develop promising activities - the production of biofuels, waste disposal of livestock complexes. For the types of products that are produced in insufficient amount, either tax exemption or an increase in state aid is required. Taking into account all the above, the state should orient the producer not just to support the production volume, but to produce environmentally friendly products.

To date, the issue of support for the development of rural areas is ambiguous. State intervention is required not only with regard to the development of rural areas in the framework of the relevant subprogram, but also the adoption of measures to increase the wages of rural workers, as one of the drivers of high-efficiency commodity production. In addition, in order for the village not to extinct, it is necessary to create new jobs that would use the released labor force.

Thus, based on the above, we can identify the factors that determine the increase in the intensity of production and labor productivity:

1. Increase of technological discipline on the basis of application of modern technologies and equipment;

2. Selection of qualified personnel;

3. Motivation of agricultural producers to reduce production costs; focus on the growth of production and specialization;

4. Implementation of internal economic relations, taking into account the interests of the staff and owners of enterprises;

5. Program-target approach to the development of agro-industrial production;

6. Preferences to agricultural producers from the state authorities, including the priority national project "Development of agriculture", which found active support of agricultural producers, and then the State Program. 


\section{Conclusions}

In modern conditions, the achievements that are available in agriculture are not enough. And in order to recognize the results of the agrarian and food policy satisfactory labor productivity should be 3-5 times higher by now on average in Russia.

For production to be effective, the rate of labor productivity growth must exceed the rate of cost growth, and the rate of cost growth cannot exceed the growth rate of prices of finished products. But such a breakthrough is possible only with active state support for innovations in agriculture and neighboring industries.

In this regard, the main priority of increasing labor productivity in agriculture should be the increase of the share of innovative products with high added value, the use of new technologies that can reduce production and circulation costs and increase the amount of gross agricultural output.

Another area of support for agro-industrial production should be innovative processes, as the acquisition of new equipment and technology is an unacceptable luxury for agricultural producers. Only a few agricultural enterprises can afford to update 15-20\% of equipment per year. It is in this area that the state should support agricultural producers. Obviously, one of the conditions for such support should be an increase in wages for villagers.

The current trend of increasing agricultural production has caused the need to save resources. Unfortunately, at present, agricultural producers do not use widely such a reserve as in-depth specialization and concentration of production. Meanwhile, specialization and concentration of agricultural production are the main factors of intensification of production, increase of labor productivity and efficiency of agricultural production.

\section{REFERENCES}

1. Russia in numbers. (2018). Brief statistical collection. Rosstat - M., 522 p.

2. Ashmarov, I. A. (2017). Some approaches to the study of the USSR' military economy in the soviet and russian national historiography. Historical Bulletin, 1(2), $19-31$.

3. Minakova, I. V. (2017). Social and economic condition of Russia and possibility of its transition to innovative hi-tech model. Modern Economy Success, 6, 24-27.

4. Gnatyuk, S. N., \& Pekert, N. A. (2018). Education as a factor of sustainable development of agriculture. Russian Economic Bulletin, 1(3), 18 - 27. 
5. Olkhovskiy, V. V. (2018). Assessment of the impact of macroeconomic and demographic factors on the Russian model of employment. Modern Economy Success, $2,31-37$.

6. Narkevich, L. V., \& Narkevich, E. A. (2018). Financial condition analysis in the crisis management system. Russian Economic Bulletin, 1(4), 10 - 24.

7. Novikov, S. V. (2017). Government stimulation and regulation of Russian innovation producers export expansion. Modern Economy Success, (3), 10-13.

8. Schwarzkopf, N. V. (2018). Improving the use of data mining technology as a way of reducing credit risk. Russian Economic Bulletin, 1(1), 10 - 18.

9. Moiseenko, Zh. N. (2017). State support of small forms of management in agroindustrial complex: state and development trends. Modern Economy Success, 4, 12-17.

10. Bogatov, H. L., Abazova, M. V., \& Yaitskaya, E. A. (2017). State regulation of employment and reduction of rural poverty in the North Caucasus Federal District. Modern Economy Success, 6, 88-92.

11. Shcherbinina, A. G. (2017). Macroeconomic perspective forecasts for business. Success of Modern Science and Education, (11-12), 102-108.

12. Moiseenko, Zh. N. (2017). State support of small forms of management in agroindustrial complex: state and development trends. Modern Economy Success, 4, 12 17.

13. Komarova, S. L. (2018). The assessment of the consumer basket for the analysis of the region competitiveness. Russian Economic Bulletin, 1(2), $19-25$.

14. Kobets, E. A. (2017). THE IMPLEMENTATION OF IMPORT SUBSTITUTION PROGRAMME IN THE AGRICULTURAL SECTOR. Современный ученый (2541-8459).

15. Kupryushin, P. A., \& Chernyatina, G. N. (2017). Economic and environmental aspects of rational nature management and optimization of the process of import substitution in the agro-industrial complex. Modern Economy Success, 3, $44-48$.

16. Narkevich, L. V. (2018). Analysis of industrial capacity and break-even production in the crisis management system. Russian Economic Bulletin, 1(3), $28-41$.

17. Vernigor, N. F. (2017). The system of state support of agricultural production (case study - the example of the Altai territory). Modern Economy Success, 6, 7 - 10.

\section{SOBRE OS AUTORES:}

\section{A.V. Kolesnikov}

Doctor of Economic Sciences (Advanced Doctor), Professor of RAS, Belgorod State Technological University named after V.G. Shukhov. E-mail: rector@intbel.ru

\section{(iD) http://orcid.org/0000-0001-8737-0933}




\section{E.Yu. Kamchatova*}

Doctor of Economic Sciences (Advanced Doctor), Associate Professor, State University of Management. E-mail: inf@guu.ru

iD http://orcid.org/0000-0002-1130-5796

\section{I.V Boyarinova}

Candidate of Sociological Sciences (Ph.D.), Associate Professor, Belgorod State National Research University. E-mail: Info@ bsu.edu.ru

iD http://orcid.org/0000-0002-0256-3187

\section{L.A. Reshetnyak}

Candidate of Economic Sciences (Ph.D.), Associate Professor, Belgorod State Agricultural University named after V.Ya. Gorin. E-mail: info@ bsaa.edu.ru

(iD) http://orcid.org/0000-0002-2558-5653

\section{O.I. Zolotareva}

Candidate of Economic Sciences (Ph.D.), Associate Professor, Belgorod State Agricultural University named after V.Ya. Gorin. E-mail: info@ bsaa.edu.ru

iD http://orcid.org/0000-0002-3652-5242

\section{S.N. Zolotarev}

Candidate of Economic Sciences (Ph.D.), Associate Professor, Belgorod State Agricultural University named after V.Ya. Gorin. E-mail: info@bsaa.edu.ru

(iD) http://orcid.org/0000-0002-1470-6974

\section{I.A. Demesheva}

Candidate of Economic Sciences (Ph.D.), Associate Professor, Belgorod State Agricultural University named after V.Ya. Gorin. E-mail: info@ bsaa.edu.ru

(iD) http://orcid.org/0000-0003-2862-1610 